\title{
Avaliação das habilidades comunicativas de crianças surdas: a influência do uso da língua de sinais e do português pelo examinador bilíngüe
}

\author{
Felipe Venâncio Barbosa ${ }^{1}$
}

Barbosa FV. Avaliação das habilidades comunicativas de crianças surdas: a influência do uso da língua de sinais e do português pelo examinador bilíngüe [tese]. São Paulo: Faculdade de Medicina, Universidade de São Paulo; 2007.

A língua de sinais ganha um novo foco no cenário nacional e a prática fonoaudiológica toma rumos que provavelmente levarão à maior difusão do bilingüismo. $\mathrm{O}$ domínio desta língua é de grande importância para o fonoaudiólogo e Contribui para diagnósticos precisos. Objetivo: analisar a comunicação de crianças surdas em interação com um examinador bilíngüe no uso das modalidades comunicativas e no perfil pragmático. Métodos: o estudo foi desenvolvido com 12 sujeitos com idade de 7 a 10 anos, com surdez profunda, sem comprometimentos associados e filhos de pais ouvintes. Aplicou-se o "Protocolo de Avaliação das Habilidades Comunicativas e de Linguagem de Crianças Surdas - Reduzido" em dois momentos: em Português e em língua de sinais. Resultados: este protocolo foi modificado para este estudo e é complementar ao protocolo original. O objetivo da redução do protocolo original é tornar sua aplicação mais concisa e rápida. Observou-se que a ocorrência de modalidade viso-espacial é maior em ambas as aplicações, mostrando a preferência desta modalidade pela criança. $\mathrm{O}$ uso de língua ocorre em maior número na aplicação em língua de sinais, indicando que a modalidade de língua usada pelo interlocutor influencia a complexidade no uso da linguagem pela criança. Com relação ao perfil pragmático o grupo exibiu maior diversidade de habilidades comunicativas na aplicação em PB, entretanto as habilidades comunicativas que predominaram nesta aplicação são menos adaptadas ao ambiente ou de aquisição precoce. As habilidades comunicativas de aquisição tardia ocorreram predominantemente na aplicação em LS. Os resultados apresentaram diferenças estatisticamente significantes com relação à complexidade do código usado para expressar as habilidades, com maior pontuação para aplicação em LS. Conclusões: Os dados sugerem a importância do conhecimento de língua de sinais pelo fonoaudiólogo pois as respostas que podem ser obtidas em um exame tendem a ser mais complexas lingüisticamente, embora não influenciadas pela modalidade usada pelo examinador.

Trabalho realizado no Departamento de Fisioterapia, Fonoaudiologia e Terapia Ocupacional da Faculdade de Medicina da Universidade de São Paulo - USP - São Paulo (SP), Brasil, para obtenção de título de Doutor em Ciências da Reabilitação, sob orientação da Profa. Dra. Ida Lichtig.

(1) Doutor, Professor Instrutor da Faculdade de Ciências Médicas da Santa Casa de São Paulo - FCMSCSP - São Paulo (SP), Brasil.

Endereço para correspondência: Felipe Venâncio Barbosa. R. Manoel José Viana, 27/14, Vila Londrina, São Paulo - SP, CEP 03731124. E-mail: felipevbarbosa@gmail.com 